CLINICAL STUDY

\title{
Prevalence of AIP mutations in a large series of sporadic Italian acromegalic patients and evaluation of CDKN1B status in acromegalic patients with multiple endocrine neoplasia
}

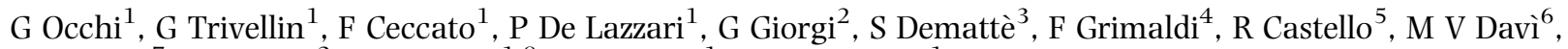 \\ $\mathrm{G}_{\text {Arnaldi }}{ }^{7}$, L Salviati ${ }^{2}$, G Opocher ${ }^{1,8}$, F Mantero $^{1}$ and C Scaroni ${ }^{1}$ \\ ${ }^{1}$ Endocrinology Division, Department of Medical and Surgical Sciences, Via Ospedale, 105, 35128 Padova, Italy, ${ }^{2}$ Clinical Genetics Unit, Department of \\ Paediatrics, University of Padova, 35128 Padova, Italy, ${ }^{3}$ S. Chiara Hospital, 38100 Trento, Italy, ${ }^{4}$ Endocrinology Division, Hospital/University Udine, \\ 33100 Udine, Italy, ${ }^{5}$ Division of Endocrinology and Metabolic Diseases, 37126 Verona, Italy, ${ }^{6}$ Clinic of Internal Medicine D, Department of Biomedical \\ and Surgical Sciences, Policlinico GB Rossi, University of Verona, 37134 Verona, Italy, ${ }^{7}$ Division of Endocrinology, Polytechnic University of Marche, \\ 60126 Ancona, Italy and ${ }^{8}$ Familial Cancer Clinic, Veneto Institute of Oncology, 35128 Padova, Italy
}

(Correspondence should be addressed to G Occhi; Email: gianluca.occhi@unipd.it)

\begin{abstract}
Background: Germline mutations in the aryl hydrocarbon receptor-interacting protein (AIP) gene and the $\mathrm{p} 27^{\mathrm{KIP} 1}$ encoding gene $C D K N 1 B$ have been associated with two well-defined hereditary conditions, familial isolated pituitary adenoma (FIPA) and multiple endocrine neoplasia type 4 (MEN4). Somatotropinomas are present in most AIP mutated FIPA kindreds, as well as in two-thirds of MEN4 patients who carry pituitary tumors.

Methods: Germline DNA samples of 131 Italian sporadic acromegalic patients including 38 individuals with multiple tumors, and of six FIPA families (four homogeneous for prolactinomas and two heterogeneous with prolactin/nonfunctioning pituitary adenomas) were collected in a multicentric collaborative study. The prevalence of $A I P$ and $C D K N 1 B$ gene point mutations and copy number variations were evaluated.

Results: Two novel (IVS3 +1G >A and c.871G >A) and one previously described (c.911G $>$ A) AIP mutations were detected in four apparently sporadic cases $(3.1 \%)$ with relatively high age at diagnosis (49 \pm 18 , range 30-67). No mutations/rearrangements were detected in FIPA families. The highly conserved c.871G $>$ A substitution was detected in a patient who also carried a MEN1 mutation suggesting that she is a double heterozygote. The possible pathogenic effect on AIP splicing of the silent substitution c.144G $>$ A found in another patient was ruled out using a minigene-based approach. CDKN1B mutations/rearrangements were neither identified in patients with multiple neoplasia nor in FIPA families.

Conclusion: AIP is mutated in about 3\% of apparently sporadic acromegalic patients. The relatively high age at diagnosis, as well as its sporadic presentation, suggests that these patients are carriers of mutations with reduced pathogenicity. p2 $7^{\mathrm{KIP} 1}$ is unlikely to represent the common unifying nonendocrine etiology for acromegaly and cancer.
\end{abstract}

European Journal of Endocrinology 163 369-376

\section{Introduction}

Acromegaly is a rare hormonal syndrome caused in at least $90 \%$ of cases by a benign GH-secreting pituitary adenoma (1). Owing to the slow rate of tumor growth, acromegalic patients are often older than 50 years of age, but when GH hypersecretion occurs in teenagers, it may cause gigantism (2). At diagnosis, tumors present as macroadenomas in more than $70 \%$ of cases (2), and in about $25 \%$ of cases, they co-secrete prolactin (3).

The majority of these tumors are sporadic, and although common oncogenes and tumor suppressor genes have been thoroughly investigated in GH-secreting adenomas, mutational changes occurring with a significant prevalence have only been detected in the GNAS1 gene that stimulate hormone secretion and somatotroph cell proliferation by perturbing cAMP levels (reviewed in (4)).

In a small proportion of cases, somatotroph tumors occur in familial settings, often as part of multiple endocrine tumors syndromes, such as multiple endocrine neoplasia type 1 (MEN1) or Carney complex (5). Germline inactivating mutations in the aryl hydrocarbon receptor-interacting protein $(A I P)$ have been identified as causing pituitary adenoma predisposition (PAP) in two Finnish and in one Italian kindreds with familial isolated pituitary adenomas (FIPAs) (6). Further studies identified AIP mutations (AIP $\left.{ }^{\mathrm{mut}}\right)$ in about $15 \%$ 
of FIPA families, including $50 \%$ of those homogeneous for somatotropinomas (7). Compared with non AIPmutated subjects, patients bearing $A I P^{\text {mut }}$ are significantly younger at diagnosis and present larger tumors (7). Conversely, AIP ${ }^{\text {mut }}$ is rare in sporadic cases (8), with the exception of young patients with GH-secreting pituitary adenomas (9-11). Although the conventional approach of direct sequencing of germline DNA identified the vast majority of $A I P^{\text {mut }}$, two out of 21 investigated FIPA families who had tested negative for AIP point mutations harbored large genomic deletion probably due to Alu-mediated recombination (12).

In about $10-20 \%$ of patients with MEN1-like features, MEN1 mutations were not identified (5). In 2006, germline mutations in the CDKN1B gene, encoding for the cyclin-dependent kinase inhibitor $\mathrm{p} 27^{\mathrm{KIP} 1}$, were associated with the development of a MEN1-like phenotype both in human and in rats, giving rise to MEN4 and MENX syndromes respectively (13). So far, germline point mutations have been reported in eight MEN4 subjects, three of which had a pituitary adenoma (14-16). Other studies, however, failed to detect CDKN1B mutations in MEN1-like patients, suggesting that such mutational events are only rarely associated with the MEN phenotype (16-18).

We report here the results of an Italian multicentric study designed to assess the prevalence of germline point mutations and gross rearrangements in AIP and correlate to associated clinical features, in an homogeneous cohort of 131 sporadic acromegalic patients, 38 of which had evidence of multiple neoplasias, and of six FIPA families. In addition, since the proven role of p $27^{\mathrm{KIP} 1}$ as tumor suppressor gene in different tissues (19), we investigated whether germline alterations in the CDKN1B gene could contribute to the higher incidence of extrapituitary neoplasia observed in acromegalic patients (20), or may have a role in familial isolated pituitary tumors.

\section{Subjects and methods}

\section{Patients}

A total of 131 acromegalic patients negative for pituitary tumors within their family and therefore considered as apparently sporadic, together with the probands of six FIPA families, were recruited at the Endocrinology Division of Padova Hospital/University, at the Verona Hospital, at the Hospital/University of Udine, at S. Chiara Hospital in Trento, and at the Division of Endocrinology and Metabolism Diseases of the Ancona Hospital. The sporadic cases were $43 \%$ men, the mean age at diagnosis was $44 \pm 13$ years (range 16-76 years), and in $89 \%$ of cases, patients presented a macroadenoma; $75 \%$ of patients underwent transsphenoidal surgery and 22\% received pituitary radiotherapy. Among FIPA families, four were
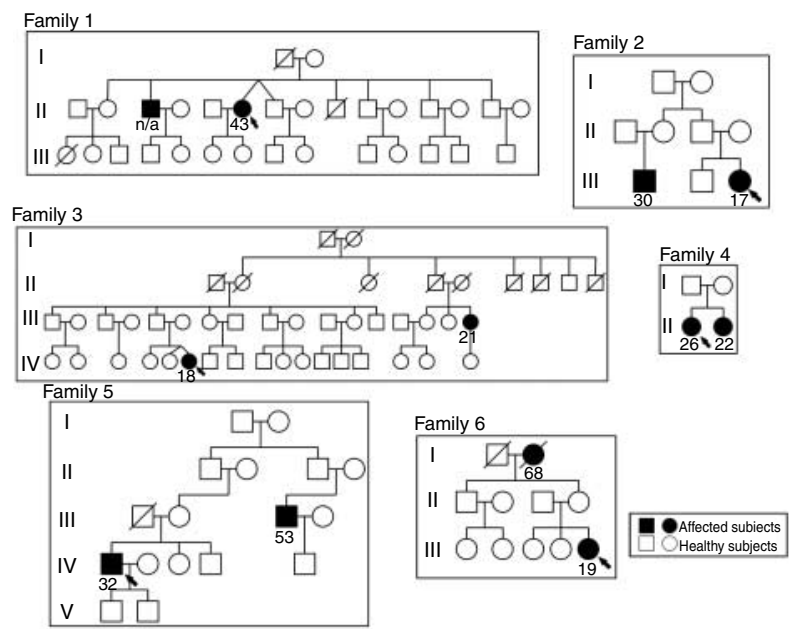

Figure 1 Pedigree structures for FIPA families. Families 1-4 were homogeneous for prolactin-secreting adenomas, while families 5 and 6 were heterogeneous for prolactin/nonfunctioning pituitary adenoma. (Subjects III 3 and I2 in families 5 and 6 respectively carry a nonfunctioning pituitary adenoma). Females and males are represented respectively with circles and squares. Probands are indicated by a black arrow. Below each subject age at diagnosis has been reported. $\mathrm{n} / \mathrm{a}=$ not available.

homogeneous for prolactin-secreting pituitary tumors and two were heterogeneous with prolactin/nonfunctioning pituitary adenomas (Fig. 1).

Diagnosis and management of pituitary disease were established for each patient by physicians at each referring center following international criteria $(2,21)$. The diagnosis of acromegaly was established with GH levels failing to drop below $1 \mu \mathrm{g} / \mathrm{l}$ after a standard glucose tolerance test or mean of seven samples above $2.5 \mu \mathrm{g} / \mathrm{l}$, high insulin-like growth factor 1 (IGF1) levels for age- and sex-related reference range, and radiological evidence of pituitary adenoma. Mutations in the MEN1 and PRKAR1A genes have been evaluated in all patients. Local ethical committees from each referring center approved the study, and all subjects gave written informed consent.

\section{Mutational analysis for AIP and CDKN1B genes}

The whole coding region, intron-exon boundaries, and $5^{\prime}$ - and $3^{\prime}$-UTRs of AIP and CDKN1B were amplified and directly sequenced as reported elsewhere (22). Previously unreported nucleotide changes in both genes and the already described AIP c.911G $>$ A variant were screened in healthy, anonymous, unrelated individuals by Tetra-primer ARMS-PCR (23) or, in the case of IVS $3+1 \mathrm{G}>\mathrm{A}$, by enzymatic digestion using MboII.

Large rearrangements at AIP locus were evaluated using the SALSA Multiplex Ligation-dependent Probe Amplification (MLPA) assay (MRC-Holland, Amsterdam, The Netherlands), following the manufacturer's protocols. 
CDKN1B gene dosage alteration was assessed by the quantitative multiplex PCR of short fluorescent fragments (QMPSFs) and by long-range PCR (LR-PCR). For QMPSF, six short genomic fragments were simultaneously amplified in a single multiplex PCR with one primer from each pair 5'-labeled with 6-FAM fluorochrome using the Multiplex PCR Master Mix $2 \times$ and the Q-solution (Qiagen). Samples underwent 24 amplification cycles, which ensured that the reaction ended during the exponential phase. An amplicon from a genomic region (19q13.3), whose deletion was not expected, was included as negative control. The amplified DNA fragments were then separated on an ABI 3730XL DNA sequencer (Applied Biosystems, Monza, Italy) and analyzed using Peak Scanner software v.1.0 (Applied Biosystems). Two different methods of comparison were used to calculate allele dosage: visual sample-to-control and numerical sample-to-control (24). For every peak, an area reduction to 0.4-0.6 compared with a control indicates a heterozygous deletion of the corresponding exon(s), whereas exonic duplications result in a 1.5-fold increase in this value.

LR-PCR on genomic DNA was used as an additional technique to detect rearrangements not detectable by QMPSF.

All primers sequences and PCR conditions are available upon request.

\section{Bioinformatic analysis}

The possible impact of novel aminoacid substitutions on AIP structure and function has been evaluated by the web tool PolyPhen (http://genetics.bwh.harvard. $\mathrm{edu} / \mathrm{pph} /)$. The impact of the IVS $3+1 \mathrm{G}>\mathrm{A}$ and c. $153 \mathrm{C}>\mathrm{T}$ on AIP splicing was tested in-silico using Alamut (http://www.interactive-biosoftware.com), a mutation interpretation software integrating the results of four different algorithms (SpliceSiteFinder, MaxEntScan, NNSPLICE, GeneSplicer). Multiple sequence alignment was performed using the ClustalW tool (http://www.ebi.ac.uk/Tools/clustalw).

\section{Minigene construction and in vitro splicing analysis}

To investigate the effect on AIP splicing of the novel synonymous variant c. $153 \mathrm{C}>\mathrm{T}$, we adopted a minigene-based strategy, as suitable mRNA from the proband was not available. The procedure and the plasmid vectors have been detailed elsewhere (25). Genomic DNA of the proband was amplified using primers containing a PstI sequence. The PCR fragment, comprising the $3^{\prime}$ half of intron 1 , exon 2 and the $5^{\prime}$ half of intron 2, was cloned into the PstI restriction site of the pEGFP-N1-COQ2-ASL5-6-7 vector (25). 0.4 $\mu \mathrm{g}$ of each wild-type $(\mathrm{Wt})$ or mutant minigene constructs were transfected into $3 \times 10^{5}$ HeLa cells using Effectene reagent (Qiagen). After 48-h incubations, RNA was extracted (Trizol kit, Invitrogen) and retrotranscribed using Superscript III kit (Invitrogen). cDNA was amplified with specific primers adjacent to the mutation to be tested.

\section{Results}

\section{Mutation analysis of the AIP gene}

The patient cohort consisted of 137 cases including 131 sporadic acromegalic patients $(95.6 \%)$ and six individuals $(4.4 \%)$ with a familial history of pituitary adenomas.

The entire AIP gene sequence was analyzed in all sporadic patients as well as in FIPA families' probands. The nucleotide changes previously described either as single-nucleotide polymorphism (SNPs) or identified in control populations were not reported.

Two sporadic patients (both females), diagnosed with acromegaly at 67 and 38 years of age, harbored the previously reported c.911G $>$ A (R304Q) substitution $(8,9,26,27)$. The in-silico evaluation by PolyPhen supported the notion that this represents a deleterious mutation. The elder patient had a history of multiple tumors (papillary thyroid carcinoma, colon polyposis, liver, and kidney cysts) and presented a pituitary macroadenoma $(18 \times 23 \mathrm{~mm})$. Her daughter died at the age of 40 years from colon carcinoma.

The younger R304Q carrier had a microadenoma $(3 \times 2 \mathrm{~mm})$ as the only clinical manifestation. Both patients achieved a good control of disease with somatostatin analogues (SAs), thus did not undergo pituitary surgery or radiotherapy.

The second nucleotide change was a missense substitution c.871G $>$ A (V291M), detected in a woman with a diagnosis of acromegaly at age 30. As shown in Fig. 2, this aminoacid is highly conserved. The PolyPhen web tool analysis predicted this variant as being deleterious. The patient underwent transsphenoidal surgery with a post-operative persistence of disease (IGF1 $556 \mu \mathrm{g} / \mathrm{l}$ and prolactin $40.5 \mu \mathrm{g} / \mathrm{l}$ respectively), and she started pharmacological treatment with SA with good clinical response. Interestingly, this patient presented also a MEN1 missense mutation (E45Q, (28)), without showing, during the clinical history, other MEN1-related symptoms.

A nucleotide substitution in the donor splice site of intron 3 (IVS3 $+1 \mathrm{G}>\mathrm{A}$ ) was identified in a female diagnosed at 62 years of age affected by a microadenoma. A malignant melanoma in her left arm had been surgically removed. All four different algorithms included in Alamut predicted that the IVS $3+1 \mathrm{G}>$ A substitution is pathogenic because it abolishes the splicing consensus.

We also detected the synonymous c.144G $>$ A (T48T) change in a patient diagnosed with acromegaly at age 74 with clinical signs of multiple tumors (benign pancreatic cysts, papillary thyroid carcinoma, tubular adenoma of the colon, and adrenal adenoma) and positive family history for epithelial neoplasia. 


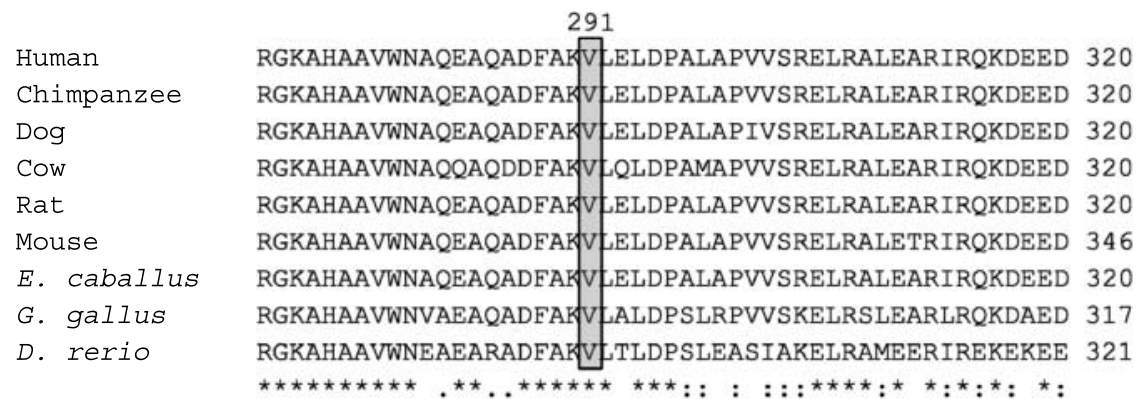

Figure 2 Comparison of valine 291 among vertebrates. Amino acid sequence homology demonstrates evolutionary conservation of valine 291 and surrounding amino acids in AIP from various species.
Because the bioinformatic prediction was inconclusive and the patient's RNA was unavailable, we employed a hybrid minigene to test the pathogenicity of this variant.

RT-PCR analysis of mRNA expressed by the AIP exon 2 minigene transfected into HeLa cells revealed that the splicing of the hybrid minigene did not differ from that of the Wt construct (see Fig. 3). Direct sequencing of the RT-PCR products confirmed correct splicing of both constructs. Taken together, these data suggest that this variant likely represents a rare neutral polymorphism.

None of the above-reported AIP variants was detected in 250 healthy controls.

An additional AIP sequence change in the $3^{\prime}$-UTR $(\mathrm{c} .993+70 \mathrm{C}>\mathrm{T})$ was detected in a sporadic acromegalic patient, and in 2 out of 90 healthy controls, suggesting that this is another neutral polymorphism.

For all the sporadic cases carrying AIP substitutions, relatives were not available for genetic studies; therefore, we were not able to perform pedigree analysis. In addition, we could not perform Loss of heterozygosity $(\mathrm{LOH})$ studies in any of the AIP variant carriers either because they did not undergo surgery or because no tumoral DNA was available to us.

AIP germline mutations were not detected in any of the FIPA families investigated.

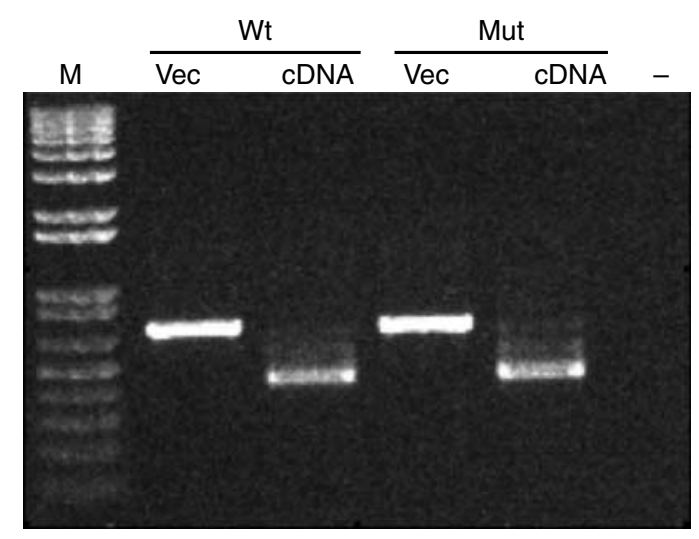

Figure $3 \mathrm{RT}$-PCR analysis of RNA derived from minigene chimeras of AIP and COQ2 expressed in HeLa cells. M, molecular marker; Wt, wild-type construct; Mut, mutant construct; - -, negative control. For each vector, plasmid DNA has been amplified as positive control (Vec).

\section{Mutation analysis of the CDKN1B gene}

Among acromegalic patients, we selected a subgroup of 38 patients characterized by multiple neoplasia, and 6 probands of FIPA families, who were studied for mutations in the CDKN1B gene. A single additional tumor was detected in 24 patients, 2 tumors in 11 patients, 3 in 2 patients, and 4 in one patient. These other neoplasms affected different tissues: colon (22 cases, 15 with colonic polyposis, 6 with tubular or villous adenoma with moderate or severe dysplasia, and 1 with adenocarcinoma), thyroid (9 patients with papillary thyroid carcinoma), adrenal glands ( 7 patients with adrenal lesions, all without endocrine secretion), liver ( 5 cases of hepatic angioma), uterus (4, fibroadenoma or leiomyoma), intracranial nonpituitary tumors (3 meningiomas), stomach (2 patients with gastric leiomyomas), other specific hystotypes were present in single cases (melanoma, lung cancer, breast, and gallbladder).

We detected two nucleotide substitutions: a synonymous c.426G $>$ A change $(\mathrm{T} 142 \mathrm{~T})$ and c. $-202 \mathrm{C}>\mathrm{T}$ nucleotide replacement in the $5^{\prime}$-UTR. Both variants were detected by Tetra-primer ARMS-PCR also in healthy controls with a frequency of 0.8 and $4.6 \%$.

\section{AIP and CDKN1B deletion analysis}

We further analyzed DNA from our cohort of sporadic and familial cases for AIP germline deletions/duplications using the MLPA technique. No evidence for the presence of large genomic rearrangement in AIP as well as in MEN1 have been identified neither in the sporadic nor in familial cases. Analogously, in patients with multiple tumors and FIPA families' probands, no rearrangements within the CDKN1B gene, evaluated both with QMPSF and LR-PCR, have been detected.

\section{Discussion}

Mutations in AIP and CDKN1B genes are involved in two well-defined conditions, namely PAP and MEN4, characterized by isolated pituitary adenomas and MEN1-like phenotype $(6,13)$.

AIP germline mutations have been reported so far in more than 60 patients, with a large majority of familial 
cases, with GH-secreting pituitary adenomas representing the most common tumor type (about $80 \%$ ) (29). Conversely, CDKN1B mutations have been described only in eight patients with MEN1-like symptoms (only one was a sporadic case), three of them having a secreting pituitary adenoma (13-15).

Here, we present data obtained in a collaborative study with the main aim of determining the prevalence of AIP and CDKN1B mutations/rearrangements in a homogeneous cohort of Italian patients with either sporadic acromegaly or a familial form of isolated pituitary tumors.

We detected three presumably pathogenic $A I P^{\text {mut }}$ in four apparently sporadic cases $(3.1 \%)$, confirming the prevalence data reported in the largest cohorts $(8,9)$. The age at diagnosis in AIP-mutated subjects within our series is relatively high compared with those reported in the other nonselected cohort of sporadic acromegalic patients (8-10), ranging from 30 to 67 years. According to previous data (29), this might be a consequence of the nature of the mutations: missense, with possibly a reduced pathogenicity in three out of four cases in this work, versus nonsense, frame-shift or affecting splice sites, hence with a strong effect on AIP function, in the other series (8-10). The vast majority of apparently sporadic AIP-mutated acromegalic patients reported so far $((8-11,26,30)$, this study) were diagnosed at an age younger than 40 years (14 out of 16 , excluding the sporadic acromegalic patients from Finland known to harbor a founder mutation). Therefore, although an age at diagnosis $<40$ may be considered a good selection criteria for AIP screening in apparently sporadic acromegalic patients, it must be considered that about $10 \%$ of patients, carrying milder $A I P^{\text {mut }}$, would be missed with such inclusion criteria.

We did not detect gross AIP rearrangements in our cohort, confirming that this is a relatively rare event in familiar cases (only two out of 27 FIPA families reported in the literature ((12), this study)), and are even more uncommon in sporadic acromegalic patients (only one in 245 patients analyzed thus far $((10,12)$, this work $))$. Therefore, this type of mutational event should be only marginally considered for molecular analysis in sporadic cases.

Although its possible pathogenic role must be confirmed by functional studies, the $A I P^{\mathrm{V} 291 \mathrm{M}}$ variant is of great interest. The contemporaneous presence of the already described $M E N 1^{\mathrm{E} 45 \mathrm{Q}}$ mutation (28) that to our knowledge is here reported for the first time suggests that this patient might be a double heterozygote. The AIP ${ }^{\mathrm{V} 291 \mathrm{M}}$ patient was not diagnosed with a severe phenotype and, at the time of the present report, she did not present any symptom of MEN1, beside the pituitary tumor. The reason of a mild phenotype may be due to different reasons. MEN1 and $A I P^{\text {mut }}$ exhibit both a reduced penetrance (about $30-40 \%$ for pituitary tumors in both cases $(29,31))$, so we cannot exclude that only one of them is fully penetrant. Although it is apparently a rare event, other cases in which MEN1 germline mutations are associated with mutations in a second tumor suppressor gene in the same patient have been described $(32,33)$. Also in these cases, the coexistence of BRCA1/BRCA2 mutations in MEN1-mutated patients did not lead to a more severe clinical phenotype as instead observed in some oligogenic disorders such as in Kallmann syndrome (involving FGFR1 and NELF) or normosmic idiopathic hypogonadotropic hypogonadism (involving FGFR 1 and GNRHR) (34). On the other hand, a high phenotypic variability could be observed also in patients with multiple mutations affecting the same tumor suppressor genes: simultaneous deletion of BMPR1a and PTEN may be associated with severe polyposis in some patients (35), but not in others (36).

Neither information on relatives' health condition nor on the segregation of AIP/MEN1 variants in her family were available; therefore, functional studies are mandatory to understand the possible combined effects of MEN1 and AIP mutations in determining pituitary phenotype.

Regarding the silent substitution c. $144 \mathrm{C}>\mathrm{T}$, albeit in principle we cannot exclude an effect on other cellular processes besides splicing of exon 2, our functional studies strongly suggest that this variant should be considered a rare polymorphism.

Six FIPA families either homogeneous for prolactinomas or heterogeneous with prolactin-secreting/ nonfunctioning pituitary adenomas were evaluated for AIP germline mutations/rearrangements without finding any causative nucleotide change. Thus, in accordance with prevalence data reported previously (7), among the seven FIPA families collected in our center - one heterogeneous with prolactin- and GHsecreting tumors was described recently $(22)-A I P^{\text {mut }}$ have been detected in a single kindred. This data further support the observation that AIP mutations play a primary role almost exclusively in families with at least one member affected with somatotropinoma.

So far only few CDKN1B-mutated MEN4 patients have been detected, thus a genotype-phenotype correlation is not univocally established. Mutations in the CDKN1B gene were found in one family with MEN1-like phenotype including GH-secreting pituitary adenomas (13), in one patient with Cushing's disease and hyperparathyroidism (14) and in three further subjects with either MEN1 or primary hyperparathyroidism but without any pituitary lesion (15). Although the frequency of pituitary tumor did not differ significantly from that described in MEN1-mutated patients (37.5 vs $42 \%$ ) (30), among the few CDKN1B-mutated subjects with a pituitary tumor, a higher prevalence of acromegalic patients was observed (67 vs 10\%) (31). Although in vitro and in vivo studies clearly support a role for the GH/IGF1 axis in tumor development, as a consequence of mitogenic and anti-apoptotic actions it exerted in many tissues (reviewed in (20)), the existence of genetic and epigenetic factors predisposing to 
GH-secreting tumors that might also predispose to the development of different cancers was recently proposed (37). Using the Swedish Family-Cancer database to analyze familial risk for pituitary adenomas and associated tumors, Hemminki et al. (37) demonstrated a significant association between $\mathrm{GH}$-secreting pituitary adenomas and the presence of different tumor types in first and second degree relatives and in the acromegalic patients themselves. Based on the role of $\mathrm{p} 27^{\mathrm{KIP} 1}$ loss in several human malignancies (19) and the increased risk of developing extrapituitary tumors in acromegalic patients (20), we hypothesized that CDKN1B mutations, leading to reduced $\mathrm{p} 27^{\mathrm{KIP} 1}$, could represent the common unifying nonendocrine etiology for acromegaly and cancer.

The silent $\mathrm{T} 142 \mathrm{~T}$ (c.426G $>\mathrm{A}$ ) substitution was detected in a 55-year-old patient affected by thyroid carcinoma, adrenal, and colon adenomas. This variant was already described in a MEN1-like patient with tumors of both the parathyroids and pituitary gland, renal angiomyolipoma, and thyroid tumor (16), in a subject with secondary hyperparathyroidism (38), in one sporadic acromegalic patient (14) and also in one case of breast carcinoma (39). Based on such observations, it was proposed that $\mathrm{T} 142 \mathrm{~T}$ might be a rare hyperparathyroidism-predisposing allele (38). In the present study, we detected the T142T allele, albeit with a low frequency $(0.8 \%)$, in our control population. Based on this and on the in-silico data that exclude its possible effect on splicing (14), we suggest that it represents a neutral polymorphism. A case-control association study on c. $426 \mathrm{G}>\mathrm{A}$, as well as functional studies, is mandatory to better understand the role of this variant in predisposing subjects to multiple cancers.

The absence of either germline or somatic mutations in $C D K N 1 B / \mathrm{p} 27^{\mathrm{KIP} 1}$ observed in sporadic GH-secreting pituitary tumors $((14,40)$, this study) suggest that their contribution to tumoral pathogenesis is probably limited. However, there is evidence, although controversial, that during the progression from normal to neoplastic pituitary, p $27^{\mathrm{KIP} 1}$ levels are decreased as a probable consequence of an impaired translational and/or post-translational mechanisms $(41,42)$.

In conclusion, AIP germline mutations play a minor role in sporadic acromegalic patients, as well as in FIPA families without any evidence of acromegaly. In addition, mutations in CDKN1B seem to play a role in multiple tumor development in acromegalic patients only within a MEN1-like phenotype, while they are unlikely the genetic cause predisposing to the higher extrapituitary cancer risk observed in these patients.

\section{Declaration of interest}

The authors declare that there is no conflict of interest that could be perceived as prejudicing the impartiality of the research reported.

\section{Funding}

This research did not receive any specific grant from any funding agency in the public, commercial, or not-for-profit sector.

\section{Acknowledgements}

The authors are grateful to Sergio Ferasin for technical assistance.

\section{References}

1 Sanno N, Teramoto A, Osamura RY, Horvath E, Kovacs K, Lloyd RV \& Scheithauer BW. Pathology of pituitary tumors. Neurosurgery Clinics of North America 200314 25-39.

2 Melmed S. Medical progress: acromegaly. New England Journal of Medicine $20063552558-2573$.

3 Al-Shraim M \& Asa SL. The 2004 World Health Organization classification of pituitary tumors: what is new? Acta Neuropathologica $20061111-7$.

4 Landis CA, Masters SB, Spada A, Pace AM, Bourne HR \& Vallar L. GTPase inhibiting mutations activate the alpha chain of Gs and stimulate adenylyl cyclase in human pituitary tumours. Nature $1989340692-696$.

5 Elston MS, McDonald KL, Clifton-Bligh RJ \& Robinson BG. Familial pituitary tumor syndromes. Nature Reviews. Endocrinology 20095 453-461.

6 Vierimaa O, Georgitsi M, Lehtonen R, Vahteristo P, Kokko A, Raitila A, Tuppurainen K, Ebeling TM, Salmela PI, Paschke R, Gündogdu S, De Menis E, Mäkinen MJ, Launonen V, Karhu A \& Aaltonen LA. Pituitary adenoma predisposition caused by germline mutations in the AIP gene. Science $20063121228-1230$.

7 Daly AF, Vanbellinghen JF, Khoo SK, Jaffrain-Rea ML, Naves LA, Guitelman MA, Murat A, Emy P, Gimenez-Roqueplo AP, Tamburrano G, Raverot G, Barlier A, De Herder W, Penfornis A, Ciccarelli E, Estour B, Lecomte P, Gatta B, Chabre O, Sabate MI, Bertagna X, Garcia Basavilbaso N, Stalldecker G, Colao A, Ferolla P, Wemeau JL, Caron P, Sadoul JL, Oneto A, Archambeaud F, Calender A, Sinilnikova O, Montanana CF, Cavagnini F, Hana V, Solano A, Delettieres D, Luccio-Camelo DC, Basso A, Rohmer V, Brue T, Bours V, Teh BT \& Beckers A. Aryl hydrocarbon receptor-interacting protein gene mutations in familial isolated pituitary adenomas: analysis in 73 families. Journal of Clinical Endocrinology and Metabolism 200792 1891-1896.

8 Georgitsi M, Raitila A, Karhu A, Tuppurainen K, Mäkinen MJ, Vierimaa O, Paschke R, Saeger W, van der Luijt RB, Sane T, Robledo M, De Menis E, Weil RJ, Wasik A, Zielinski G, Lucewicz O, Lubinski J, Launonen V, Vahteristo P \& Aaltonen LA. Molecular diagnosis of pituitary adenoma predisposition caused by aryl hydrocarbon receptor-interacting protein gene mutations. PNAS 2007104 4101-4105.

9 Cazabat L, Libe R, Perlemoine K, Rene-Corail F, Burnichon N, Gimenez-Roqueplo AP, Dupasquier-Fediaevsky L, Bertagna X, Clauser E, Chanson P, Bertherat J \& Raffin-Sanson ML. Germlineinactivating mutations of the aryl hydrocarbon receptorinteracting protein gene in a large cohort of sporadic acromegaly: mutations are found in a subset of young patients with macroadenomas. European Journal of Endocrinology 2007157 1-8.

10 Barlier A, Vanbellinghen JF, Daly AF, Silvy M, Jaffrain-Rea ML, Trouillas J, Tamagno G, Cazabat L, Bours V, Brue T, Enjalbert A \& Beckers A. Mutations in the aryl hydrocarbon receptor interacting protein gene are not highly prevalent among subjects with sporadic pituitary adenomas. Journal of Clinical Endocrinology and Metabolism 200792 1952-1955.

11 Georgitsi M, De Menis E, Cannavò S, Mäkinen MJ, Tuppurainen K, Pauletto P, Curtò L, Weil RJ, Paschke R, Zielinski G, Wasik A, Lubinski J, Vahteristo P, Karhu A \& Aaltonen LA. Aryl hydrocarbon receptor interacting protein (AIP) gene mutation analysis in children and adolescents with sporadic pituitary adenomas. Clinical Endocrinology $200869621-627$. 
12 Georgitsi M, Heliövaara E, Paschke R, Kumar AV, Tischkowitz M, Vierimaa O, Salmela $\mathrm{P}$, Sane T, De Menis E, Cannavò S, Gündogdu S, Lucassen A, Izatt L, Aylwin S, Bano G, Hodgson S, Koch CA, Karhu A \& Aaltonen LA. Large genomic deletions in AIP in pituitary adenoma predisposition. Journal of Clinical Endocrinology and Metabolism 200893 4146-4151.

13 Pellegata NS, Quintanilla-Martinez L, Siggelkow H, Samson E, Bink K, Höfler H, Fend F, Graw J \& Atkinson MJ. Germ-line mutations in p27 Kip1 cause a multiple endocrine neoplasia syndrome in rats and humans. PNAS 2006103 15558-15563.

14 Georgitsi M, Raitila A, Karhu A, van der Luijt RB, Aalfs CM, Sane T, Vierimaa O, Mäkinen MJ, Tuppurainen K, Paschke R, Gimm O, Koch CA, Gündogdu S, Lucassen A, Tischkowitz M, Izatt L, Aylwin S, Bano G, Hodgson S, De Menis E, Launonen V, Vahteristo P \& Aaltonen LA. Germline CDKN1B/p2 $7^{\text {Kip1 }}$ mutation in multiple endocrine neoplasia. Journal of Clinical Endocrinology and Metabolism 200792 3321-3325.

15 Agarwal SK, Mateo CM \& Marx SJ. Rare germline mutations in cyclin-dependent kinase inhibitor genes in multiple endocrine neoplasia type 1 and related states. Journal of Clinical Endocrinology and Metabolism 200994 1826-1834.

16 Ozawa A, Agarwal SK, Mateo CM, Burns AL, Rice TS, Kennedy PA, Quigley CM, Simonds WF, Weinstein LS, Chandrasekharappa SC, Collins FS, Spiegel AM \& Marx SJ. The parathyroid/pituitary variant of multiple endocrine neoplasia type 1 usually has causes other than p2 $7^{\mathrm{Kip} 1}$ mutations. Journal of Clinical Endocrinology and Metabolism 200792 1948-1951.

17 Owens M, Stals K, Ellard S \& Vaidya B. Germline mutations in the CDKN1B gene encoding $\mathrm{p} 27^{\mathrm{Kip} 1}$ are a rare cause of multiple endocrine neoplasia type 1. Clinical Endocrinology 200970 499-500.

18 Igreja S, Chahal HS, Akker SA, Gueorguiev M, Popovic V, Damjanovic S, Wass JA, Quinton R, Grossman AB \& Korbonits M. Assessment of p27 (cyclin-dependent kinase inhibitor 1B) and AIP (aryl hydrocarbon receptor-interacting protein) genes in MEN1 syndrome patients without any detectable MEN1 gene mutations. Clinical Endocrinology 200870 259-264.

19 Chu IM, Hengst L \& Slingerland JM. The Cdk inhibitor p27 in human cancer: prognostic potential and relevance to anticancer therapy. Nature Reviews. Cancer 2008 8 253-267.

20 Loeper S \& Ezzat S. Acromegaly: re-thinking the cancer risk. Reviews in Endocrine \& Metabolic Disorders 20089 41-58.

21 Casanueva FF, Molitch ME, Schlechte JA, Abs R, Bonert V, Bronstein MD, Brue T, Cappabianca P, Colao A, Fahlbusch R, Fideleff H, Hadani M, Kelly P, Kleinberg D, Laws E, Marek J, Scanlon M, Sobrinho LG, Wass JA \& Giustina A. Guidelines of the Pituitary Society for the diagnosis and management of prolactinomas. Clinical Endocrinology 200665 265-273.

22 Occhi G, Jaffrain-Rea ML, Trivellin G, Albiger N, Ceccato F, De Menis E, Angelini M, Ferasin S, Beckers A, Mantero F \& Scaroni C. The R304X mutation of the aryl hydrocarbon receptor interacting protein gene in familial isolated pituitary adenomas: mutational Hot-Spot or founder effect? Journal of Endocrinological Investigation 2010 In press.

23 Ye S, Dhillon S, Ke X, Collins AR \& Day IN. An efficient procedure for genotyping single nucleotide polymorphisms. Nucleic Acids Research 200129 E88.

24 Castellsagué E, González S, Nadal M, Campos O, Guinó E, Urioste M, Blanco I, Frebourg T \& Capellá G. Detection of APC gene deletions using quantitative multiplex PCR of short fluorescent fragments. Clinical Chemistry $2008 \mathbf{5 4} 1132-1140$.

25 Trevisson E, Salviati L, Baldoin MC, Toldo I, Casarin A, Sacconi S, Cesaro L, Basso G \& Burlina AB. Argininosuccinate lyase deficiency: mutational spectrum in Italian patients and identification of a novel ASL pseudogene. Human Mutation $2007 \mathbf{2 8}$ 694-702.

26 Leontiou CA, Gueorguiev M, van der Spuy J, Quinton R, Lolli F, Hassan S, Chahal HS, Igreja SC, Jordan S, Rowe J, Stolbrink M, Christian HC, Wray J, Bishop-Bailey D, Berney DM, Wass JA, Popovic V, Ribeiro-Oliveira A Jr, Gadelha MR, Monson JP, Akker SA, Davis JR, Clayton RN, Yoshimoto K, Iwata T,
Matsuno A, Eguchi K, Musat M, Flanagan D, Peters G, Bolger GB, Chapple JP, Frohman LA, Grossman AB \& Korbonits M. The role of the aryl hydrocarbon receptor-interacting protein gene in familial and sporadic pituitary adenomas. Journal of Clinical Endocrinology and Metabolism 200893 2390-2401.

27 Vargiolu M, Fusco D, Kurelac I, Dirnberger D, Baumeister R, Morra I, Melcarne A, Rimondini R, Romeo G \& Bonora E. The tyrosine kinase receptor RET interacts in vivo with AIP to alter survivin availability. Journal of Clinical Endocrinology and Metabolism 200994 2571-2578.

28 Ellard S, Hattersley AT, Brewer CM \& Vaidya B. Detection of an MEN1 gene mutation depends on clinical features and supports current referral criteria for diagnostic molecular genetic testing. Clinical Endocrinology 200562 169-175.

29 Cazabat L, Guillaud-Bataille M, Bertherat J \& Raffin-Sanson ML. Mutations of the gene for the aryl hydrocarbon receptorinteracting protein in pituitary adenomas. Hormone Research 200971 132-141.

30 Stratakis CA, Tichomirowa MA, Boikos S, Azevedo MF, Lodish M, Martari M, Verma S, Daly AF, Raygada M, Keil MF, Papademetriou J, Drori-Herishanu L, Horvath A, Tsang KM, Nesterova M, Franklin S, Vanbellinghen J-F, Bours V, Salvatori R \& Beckers A. The role of germline AIP, MEN1, PRKAR1A, CDKN1B and CDKN2C mutations in a large cohort of children and adolescents with pituitary adenomas. Clinical Genetics 2010 In press.

31 Vergès B, Boureille F, Goudet P, Murat A, Beckers A, Sassolas G, Cougard P, Chambe B, Montvernay C \& Calender A. Pituitary disease in MEN type 1 (MEN1): data from the France-Belgium MEN1 multicenter study. Journal of Clinical Endocrinology and Metabolism $2002 \mathbf{8 7} 457-465$.

32 Ghataorhe P, Kurian AW, Pickart A, Trapane P, Norton JA, Kingham K \& Ford JM. A carrier of both MEN1 and BRCA2 mutations: case report and review of the literature. Cancer Genetics and Cytogenetics $2007 \mathbf{1 7 9} 89-92$.

33 Papi L, Palli D, Masi L, Putignano AL, Congregati C, Zanna I, Marini F, Giusti F, Luzi E, Tonelli F, Genuardi M, Brandi ML \& Falchetti A. Germline mutations in MEN1 and BRCA1 genes in a woman with familial multiple endocrine neoplasia type 1 and inherited breast-ovarian cancer syndromes: a case report. Cancer Genetics and Cytogenetics 2009195 75-79.

34 Pitteloud N, Quinton R, Pearce S, Raivio T, Acierno J, Dwyer A, Plummer L, Hughes V, Seminara S, Cheng YZ, Li WP, Maccoll G, Eliseenkova AV, Olsen SK, Ibrahimi OA, Hayes FJ, Boepple P, Hall JE, Bouloux P, Mohammadi M \& Crowley W. Digenic mutations account for variable phenotypes in idiopathic hypogonadotropic hypogonadism. Journal of Clinical Investigation 2007 $117457-463$.

35 Delnatte C, Sanlaville D, Mougenot JF, Vermeesch JR, Houdayer C, Blois MC, Genevieve D, Goulet O, Fryns JP, Jaubert F, Vekemans M, Lyonnet S, Romana S, Eng C \& Stoppa-Lyonnet D. Contiguous gene deletion within chromosome arm 10q is associated with juvenile polyposis of infancy, reflecting cooperation between the BMPR1A and PTEN tumor-suppressor genes. American Journal of Human Genetics 200678 1066-1074.

36 Salviati L, Patricelli M, Guariso G, Sturniolo GC, Alaggio R, Bernardi F, Zuffardi O \& Tenconi R. Deletion of PTEN and BMPR1A on chromosome 10q23 is not always associated with juvenile polyposis of infancy. American Journal of Human Genetics $2006 \mathbf{7 9}$ 593-596.

37 Hemminki K, Försti A \& Ji J. Incidence and familial risks in pituitary adenoma and associated tumors. Endocrine-Related Cancer 200714 103-109.

38 Lauter $\mathrm{KB} \&$ Arnold A. Mutational analysis of $C D K N 1 B$, a candidate tumor-suppressor gene, in refractory secondary/tertiary hyperparathyroidism. Kidney International 200873 1137-1140.

39 Spirin KS, Simpson JF, Takeuchi S, Kawamata N, Miller CW \& Koeffler HP. p27/Kip1 mutation found in breast cancer. Cancer Research 199656 2400-2404. 
40 Takeuchi S, Koeffler HP, Hinton DR, Miyoshi I, Melmed S \& Shimon I. Mutation and expression analysis of the cyclindependent kinase inhibitor gene p27/Kip1 in pituitary tumors. Journal of Endocrinology 1998157 337-341.

41 Bamberger CM, Fehn M, Bamberger AM, Lüdecke DK, Beil FU, Saeger W \& Schulte HM. Reduced expression levels of the cell-cycle inhibitor p2 $7^{\mathrm{Kip} 1}$ in human pituitary adenomas. European Journal of Endocrinology 1999140 250-255.
42 Muşat M, Morris DG, Korbonits M \& Grossman AB. Cyclins and their related proteins in pituitary tumourigenesis. Molecular and Cellular Endocrinology 2010 In press.

Received 14 May 2010

Accepted 7 June 2010 